Article

\title{
Pyrrole Alkaloids from the Edible Mushroom Phlebopus portentosus with Their Bioactive Activities
}

\author{
Zhaocui Sun ${ }^{\dagger}$, Meigeng $\mathrm{Hu}^{\dagger}{ }^{\dagger}$, Zhonghao Sun, Nailiang Zhu, Junshan Yang, Guoxu Ma * and \\ Xudong $\mathrm{Xu}$ * \\ Key Laboratory of Bioactive Substances and Resource Utilization of Chinese Herbal Medicine, \\ Ministry of Education, Beijing Key Laboratory of Innovative Drug Discovery of Traditional Chinese \\ Medicine (Natural Medicine) and Translational Medicine, Key Laboratory of Efficacy Evaluation of Chinese \\ Medicine against Glycolipid Metabolic Disorders, State Administration of Traditional Chinese Medicine, \\ Institute of Medicinal Plant Development, Peking Union Medical College and Chinese Academy of Medical \\ Sciences, Beijing 100193, China; flydancingsun@163.com (Z.S.); humeigeng@outlook.com (M.H.); \\ sun_zhonghao@126.com (Z.S.); nlzhu@implad.ac.cn (N.Z.); jsyang@implad.ac.cn (J.Y.) \\ * Correspondence: mgxfl8785@163.com (G.M.); xdxu2012@163.com (X.X.); Tel.: +86-010-5783-3296 (G.M.) \\ † These authors contributed equally to this work.
}

Received: 16 April 2018; Accepted: 14 May 2018; Published: 17 May 2018

\begin{abstract}
Seven pyrrole alkaloids, three of which are novel (phlebopines A-C (1-3)), were isolated from the fruiting bodies of the edible mushroom Phlebopus portentosus. Their structures were determined on the basis of spectroscopic data. All the isolated compounds were tested for their neuroprotective properties and acetylcholine esterase ( $\mathrm{AChE}$ ) inhibition activities. Compound 7 displayed remarkable neuroprotective effects against hydrogen peroxide $\left(\mathrm{H}_{2} \mathrm{O}_{2}\right)$-induced neuronal-cell damage in human neuroblastoma SH-SY5Y cells.
\end{abstract}

Keywords: Phlebopus portentosus; edible mushroom; pyrrole alkaloids; neuroprotection

\section{Introduction}

Edible mushrooms are very popular with the public due to their pleasant taste, low energy, fat content, and health properties [1,2]. Additionally, the extractions of some edible mushrooms display various human health benefits, such as neuroprotective activity, antifatigue ability, improved immunity, cough relief, reduced sputum, and antitumor properties [3-6]. In recent years, edible mushrooms have attracted much attention from chemists and biologists because their components contain novel structures and diverse bioactivities. Terreumols with a rare 10-membered ring system display remarkable cyctoxicities against five human cancer cell lines, and were isolated from the fruiting bodies of edible mushroom Tricholoma terreum [5]. Matsutakone is an acetylcholinesterase inhibitor with an unprecedented polycyclic ring system derived from the edible mushroom Tricholoma matsutake [6].

Phlebopus portentosus (Berk. and Broome) Boedijin is an edible mushroom with a wide distribution in tropical parts of China, especially in the Yunnan, Guangxi, and Hannan provinces [7]. It is very popular for its prized flavor and large black fruiting body, which is rich in protein, crude fat, polysaccharide, crude fiber, mineral elements, and amino acids [8,9]. However, the pharmacological activity and active material basis of this species have not been researched. In our screening program for the neuroprotective activity of edible mushrooms, the ethyl acetate extraction of $P$. portentosus exhibited moderate activity against $\mathrm{H}_{2} \mathrm{O}_{2}$ induced damage in SH-SY5Y neuroblastma cells. With the purpose of finding new neuroprotective compounds, we examined the AcOEt extraction of P. portentosus, and found three new pyrrole alkaloids, and phlebopines A-C (1-3), along with four known ones: 2-[2-formyl-5-(methoxymethyl)-1H-pyrrole-1-yl]propanoate (4) [10], 
inotopyrrole (5) [11], 1-isopentyl-2-formyl-5-hydroxy-methylpyrrole (6) [12], and inotopyrrole B (7) [13] (Figure 1). This paper reports the isolation and structural elucidation of the isolated pyrrole alkaloids, as well as their neuroprotection and acetylcholine esterase (AChE) inhibition.

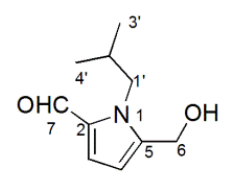

1

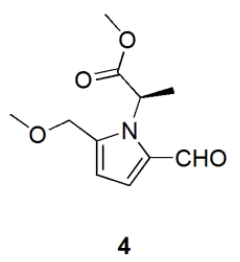

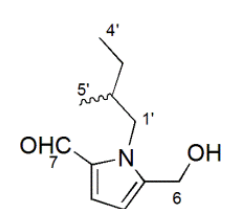

2

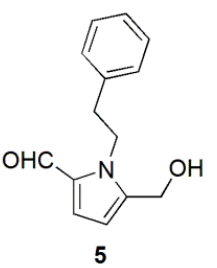

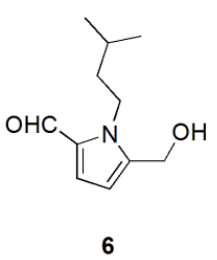

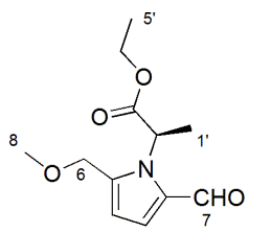

3

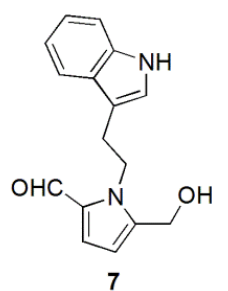

Figure 1. Structures of compounds 1-7.

\section{Results}

\subsection{Structure Elucidation}

Compound 1, was purified as a white powder, and has a molecular formula of $\mathrm{C}_{10} \mathrm{H}_{15} \mathrm{NO}_{2}$ which was deduced by a HRESIMS quasimolecular ion at $m / z 204.0997$ [M $+\mathrm{Na}]^{+}$(calculated for $\mathrm{C}_{10} \mathrm{H}_{15} \mathrm{NO}_{2} \mathrm{Na}$, 204.1000). It had an IR absorption band at $1647 \mathrm{~cm}^{-1}$, which suggested the presence of an unsaturated carbonyl group. An absorption band at $291 \mathrm{~nm}$ in the UV spectrum of compound 1 was indicative of a pyrrole-2-aldehyde moiety [14]. The ${ }^{1} \mathrm{H}-\mathrm{NMR}$ spectrum (Table 1, supplementary material Figure S1) displayed a set of two mutual coupled protons at $\delta_{\mathrm{H}} 6.98(1 \mathrm{H}, \mathrm{d}, J=4.2 \mathrm{~Hz}, \mathrm{H}-3)$ and $6.23(1 \mathrm{H}, \mathrm{d}, J=4.2 \mathrm{~Hz}, \mathrm{H}-4)$, which indicated the presence of a typical 2,5-disubstituted pyrrole ring $[15,16]$. The presence of an aldehyde group in compound $\mathbf{1}$ was supported by the NMR signals at $\delta_{\mathrm{H}} 9.44(1 \mathrm{H}, \mathrm{s})$ and $\delta_{\mathrm{C}} 179.5$. Two oxygenated protons at $\delta_{\mathrm{H}} 4.50(\mathrm{~s}, 2 \mathrm{H})$, together with the downfield methylene carbon signal at $\delta_{\mathrm{C}} 55.6$, suggested the existence of a hydroxymethyl group. ${ }^{1} \mathrm{H}-\mathrm{NMR}$ signals of $\delta_{\mathrm{H}} 0.80\left(6 \mathrm{H}, \mathrm{d}, J=7.2 \mathrm{~Hz}\right.$, overlapped, H-3 $\left.{ }^{\prime} / 4^{\prime}\right), 2.00\left(1 \mathrm{H}, \mathrm{m}, \mathrm{H}-2^{\prime}\right), 4.11\left(2 \mathrm{H}, \mathrm{d}, J=7.8 \mathrm{~Hz}, \mathrm{H}-1^{\prime}\right)$, and ${ }^{13} \mathrm{C}$-NMR APT (Table 1, supplementary material Figure S2) signals of $\delta_{\mathrm{C}} 19.9$ (overlapped), 30.1, and 51.9 indicated the presence of an isobutyl moiety, which was further confirmed by ${ }^{1} \mathrm{H}-{ }^{1} \mathrm{H} \mathrm{COSY}$ correlations of $\mathrm{H}-3^{\prime} / \mathrm{H}-2^{\prime} / \mathrm{H}-1^{\prime}$ (Figure 2). In the HMBC spectrum (Figure 2), the aldehyde proton had a long-range correlation with C-2 $\left(\delta_{C} 132.4\right)$, while hydroxymethyl protons showed enhancements with $C-5\left(\delta_{C} 144.5\right)$, which suggests that the two groups were located at C-2 and C-5 of the pyrrole ring, respectively. The isobutyl side chain was attached to the $\mathrm{N}$ atom on the basis of $\mathrm{HMBC}$ correlations from $\mathrm{H}-1^{\prime}\left(\delta_{\mathrm{H}} 4.11\right)$ to $\mathrm{C}-2$ and $\mathrm{C}-5$, together with the downfield methine carbon of $\mathrm{C}-1^{\prime}\left(\delta_{\mathrm{C}} 51.9\right)$. Thus, the entire structure of compound 1 was elucidated as 1-isobutyl-2-formyl-5-hydroxymethylpyrrole, and given the trivial name phlebopine A.

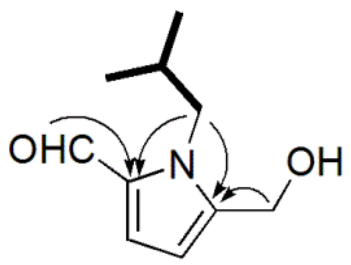

Figure 2. Key ${ }^{1} \mathrm{H}-{ }^{1} \mathrm{H}$ COSY (bolded items) and $\mathrm{HMBC}$ (arrows) correlations of compound $\mathbf{1}$. 
Table 1. NMR spectral data of $\mathbf{1}-\mathbf{3}$ (600 MHz for ${ }^{1} \mathrm{H}-\mathrm{NMR}$ and $150 \mathrm{MHz}$ for $\left.{ }^{13} \mathrm{C}-\mathrm{NMR}\right)$.

\begin{tabular}{|c|c|c|c|c|c|c|}
\hline \multirow{2}{*}{ No. } & \multicolumn{2}{|c|}{$1^{a}$} & \multicolumn{2}{|r|}{$2^{a}$} & \multicolumn{2}{|c|}{$3^{b}$} \\
\hline & $\delta_{\mathrm{C}}$, Type & $\delta_{\mathrm{H}}(J$ in $\mathrm{Hz})$ & $\delta_{\mathrm{C}}$, Type & $\delta_{\mathrm{H}}(J$ in $\mathrm{Hz})$ & $\delta_{\mathrm{C}}$, Type & $\delta_{\mathrm{H}}(\mathrm{J}$ in $\mathrm{Hz})$ \\
\hline 1 & - & - & - & - & - & - \\
\hline 2 & 132.4, C & - & $132.5, \mathrm{C}$ & - & $132.5, \mathrm{C}$ & - \\
\hline 3 & $124.6^{c}, \mathrm{CH}$ & $6.98, \mathrm{~d}(4.2)$ & $124.7^{c}, \mathrm{CH}$ & $6.98, \mathrm{~d}(4.2)$ & $125.0, \mathrm{CH}$ & $6.95, \mathrm{~d}(4.2)$ \\
\hline 4 & $110.0, \mathrm{CH}$ & $6.23, \mathrm{~d}(4.2)$ & $110.0, \mathrm{CH}$ & $6.22, \mathrm{~d}(4.2)$ & $111.8, \mathrm{CH}$ & $6.26, \mathrm{~d}(4.2)$ \\
\hline 5 & $144.5, \mathrm{C}$ & - & $144.6, \mathrm{C}$ & - & $139.2^{c}, C$ & - \\
\hline 6 & $55.6, \mathrm{CH}_{2}$ & $4.50, \mathrm{~s}$ & $55.6, \mathrm{CH}_{2}$ & $4.49, \mathrm{~s}$ & $65.8, \mathrm{CH}_{2}$ & $\begin{array}{l}4.48 \text {, d (13.2) } \\
4.42 \text {, d (13.2) }\end{array}$ \\
\hline 7 & $179.5, \mathrm{CH}$ & $9.44, \mathrm{~s}$ & $179.5, \mathrm{CH}$ & $9.44, \mathrm{~s}$ & $178.9, \mathrm{CH}$ & $9.43, \mathrm{~s}$ \\
\hline 8 & - & - & - & - & 57.6, $\mathrm{CH}_{3}$ & $3.31, \mathrm{~s}$ \\
\hline $1^{\prime}$ & $51.9, \mathrm{CH}$ & $4.11, \mathrm{~d}(7.8)$ & $50.8, \mathrm{CH}_{2}$ & $4.12, \mathrm{~m} ; 4.20, \mathrm{~m}$ & $17.7, \mathrm{CH}_{3}$ & $1.70, \mathrm{~d}(7.2)$ \\
\hline $2^{\prime}$ & $30.1, \mathrm{CH}$ & $2.00, \mathrm{~m}$ & $36.5, \mathrm{CH}$ & $1.79, \mathrm{~m}$ & $54.7, \mathrm{CH}$ & $4.00, \mathrm{~m}$ \\
\hline $3^{\prime}$ & $19.9, \mathrm{CH}_{3}$ & $0.80, \mathrm{~d}(7.2)$ & 26.7, $\mathrm{CH}_{2}$ & $1.12, \mathrm{~m} ; 1.25, \mathrm{~m}$ & $170.1^{\mathrm{c}}, \mathrm{C}$ & - \\
\hline $4^{\prime}$ & $19.9, \mathrm{CH}_{3}$ & $0.80, \mathrm{~d}(7.2)$ & $11.7, \mathrm{CH}_{3}$ & $0.84, \mathrm{t}(7.2)$ & $61.5, \mathrm{CH}_{2}$ & $4.17, \mathrm{~m}$ \\
\hline $5^{\prime}$ & & & $16.7, \mathrm{CH}_{3}$ & $0.73, \mathrm{~d}(6.6)$ & $14.1, \mathrm{CH}_{3}$ & $1.21, \mathrm{t}(7.2)$ \\
\hline
\end{tabular}

a Spectra data were recorded in DMSO- $d_{6} ;{ }^{\mathrm{b}}$ Spectra data were recorded in $\mathrm{CDCl}_{3} ;{ }^{\mathrm{c}}$ Data were observed from HSQC and HMBC spectra.

Compound 2 was obtained as a white powder with the molecular formula of $\mathrm{C}_{11} \mathrm{H}_{17} \mathrm{NO}_{2}$ based on the positive ion HRESIMS peak at $m / z 218.1132[\mathrm{M}+\mathrm{Na}]^{+}$(calculated for $\mathrm{C}_{11} \mathrm{H}_{17} \mathrm{NO}_{2} \mathrm{Na}$, 218.1157). The ${ }^{1} \mathrm{H}$ - and ${ }^{13} \mathrm{C}$-NMR spectroscopic data (Table 1 ) of compound 2 were quite similar to those of compound 1 except for the additional methylene $\left(\delta_{\mathrm{H}} 1.12,1.25 ; \delta_{\mathrm{C}} 26.7\right)$. Further comparison of the NMR data between compounds $\mathbf{1}$ and $\mathbf{2}$ revealed that one methyl group at $\mathrm{C}-2^{\prime}$ in $\mathbf{1}$ was replaced by an ethyl group in compound 2. The proton signals at $\delta_{\mathrm{H}} 0.84\left(\mathrm{t}, J=7.2 \mathrm{~Hz}, \mathrm{H}-4^{\prime}\right), 1.12\left(1 \mathrm{H}, \mathrm{m}, \mathrm{H}-3^{\prime} \mathrm{a}\right)$, and $1.25\left(1 \mathrm{H}, \mathrm{m}, \mathrm{H}-3^{\prime} \mathrm{b}\right)$, together with their $\mathrm{HMBC}$ correlations from $\mathrm{H}-4^{\prime}$ and $\mathrm{H}-3^{\prime}$, confirmed the deduction above. However, the absence of proper model compounds to use as references made the assignment of the absolute configuration at $\mathrm{C}-2^{\prime}$ unreliable. Therefore, compound $\mathbf{2}$ was identified as 1-(2-methybutyl)-2-formyl-5-hydroxyl-methylpyrrole, and given the trivial name phlebopine $\mathrm{B}$.

Compound 3, was obtained as a white amorphous powder, with its molecular formula assigned as $\mathrm{C}_{12} \mathrm{H}_{17} \mathrm{NO}_{4}$ on the basis of its positive HRESIMS $\left(\mathrm{m} / z 262.1034[\mathrm{M}+\mathrm{Na}]^{+}\right)$, implying 5 degrees of unsaturation. The ${ }^{1} \mathrm{H}-\mathrm{NMR}$ spectrum (Table 1 ) displayed 2-aldehyde-5-hdyroxymethyl-pyrrole unit signals at $\delta_{\mathrm{H}} 6.95(1 \mathrm{H}, \mathrm{d}, J=4.2 \mathrm{~Hz}, \mathrm{H}-3)$ and $6.26(1 \mathrm{H}, \mathrm{d}, J=4.2 \mathrm{~Hz}, \mathrm{H}-4), 4.48(1 \mathrm{H}, \mathrm{d}, J=13.2 \mathrm{~Hz}, \mathrm{Ha})$, $4.42(1 \mathrm{H}, \mathrm{d}, J=13.2 \mathrm{~Hz}, \mathrm{Hb})$, and $9.43(\mathrm{~s})$, which indicated that compound 3 was an analogue of compound 1. Other signals of methoxyl appeared at $\delta_{\mathrm{H}} 3.31$, ethoxyl at $\delta_{\mathrm{H}} 1.21(3 \mathrm{H}), 4.17(2 \mathrm{H})$, methyl at $\delta_{\mathrm{H}} 1.70$, and methine at $\delta_{\mathrm{H}} 4.00$. Except for the 2,5-disubstituted pyrrole moiety and one ester carbonyl $\left(\delta_{\mathrm{C}} 170.1\right)$, the ${ }^{13} \mathrm{C}-\mathrm{NMR}$ APT (Table 1$)$ showed another five carbon signals corresponding to the groups above. In the HMBC spectrum, the methyl signals at $\delta_{\mathrm{H}} 1.70\left(3 \mathrm{H}, \mathrm{s}, \mathrm{H}-1^{\prime}\right)$ had correlations with $\mathrm{C}-2^{\prime}\left(\delta_{\mathrm{C}} 54.7\right)$ and $\mathrm{C}-3^{\prime}\left(\delta_{\mathrm{C}} 170.1\right)$, indicating the presence of a $-\mathrm{CH}\left(\mathrm{CH}_{3}\right) \mathrm{CO}$ - unit. The downfield chemical shift of $\mathrm{C}-2^{\prime}\left(\delta_{\mathrm{C}} 54.7\right)$ as well as the HMBC correlations between $\mathrm{H}-2^{\prime}$ and $\mathrm{C}-2$ suggested the $-\mathrm{CH}\left(\mathrm{CH}_{3}\right) \mathrm{CO}$ - unit was attached to the $\mathrm{N}$ atom of pyrrole ring. Furthermore, the HMBC correlations between $\delta_{\mathrm{H}} 3.31\left(-\mathrm{OCH}_{3}\right)$ and $\mathrm{C}-6\left(\delta_{\mathrm{C}} 65.8\right), \delta_{\mathrm{H}} 4.17\left(-\mathrm{OCH}_{2}-\right)$ and $\mathrm{C}-3^{\prime}\left(\delta_{\mathrm{C}} 170.1\right)$ indicated the methoxyl and ethoxyl groups were located at C- 6 and C-3', respectively. The CD spectrum of compound 3 exhibited a negative Cotton effect at $330(\Delta \varepsilon 8.7) \mathrm{nm}$ due to the conjugated pyrrole ring chromophore, suggesting an $R$ absolute configuration for C-2' [10]. As a result, compound 3 was established as 1-ethylpropionate-2-formyl-5-methoxylmethylpyrrole, and given the trivial name phlebopine $\mathrm{C}$.

\subsection{Bioactive Activity}

All the compounds were evaluated for their neuroprotection and acetylcholine esterase (AChE) inhibition activities. The results (Table 2 ) showed that compound 7 could significantly attenuate SH-SY5Y cell damage induced by $\mathrm{H}_{2} \mathrm{O}_{2}$ with a $26.5 \%$ increase in cell survival over the $\mathrm{H}_{2} \mathrm{O}_{2}$ group at $10 \mu \mathrm{M}$, compared with the positive control $\mathrm{N}$-acetyl-L-cysteine causing a $24.3 \%$ increase in cell 
viability over the $\mathrm{H}_{2} \mathrm{O}_{2}$ group at a concentration of $10 \mu \mathrm{M}$. Other compounds displayed moderate or mild activities, ranging from a $5.84 \%$ to $15.7 \%$ increase in cell survival over the $\mathrm{H}_{2} \mathrm{O}_{2}$ group at $10 \mu \mathrm{M}$. However, none of the compounds have significant inhibitory activity against AChE at the concentration of $10 \mu \mathrm{M}$.

Table 2. Effect of isolated compounds on SH-SY5Y cell damage induced by $\mathrm{H}_{2} \mathrm{O}_{2}$.

\begin{tabular}{cc}
\hline Compounds & Cell Viability (\% of Control) \\
\hline $\mathbf{1}$ & $54.57 \pm 0.97^{\mathrm{a}}$ \\
$\mathbf{2}$ & $57.62 \pm 3.42$ \\
$\mathbf{3}$ & $60.27 \pm 2.38$ \\
$\mathbf{5}$ & $62.58 \pm 3.32$ \\
$\mathbf{6}$ & $64.43 \pm 1.57$ \\
$\mathbf{7}$ & $59.31 \pm 2.01$ \\
$\mathrm{~N}$-acetyl-L-cysteine ${ }^{\mathrm{b}}$ & $75.23 \pm 1.76$ \\
$\mathrm{H}_{2} \mathrm{O}_{2}$ control & $73.03 \pm 1.49$ \\
Blank control & $48.73 \pm 1.08$ \\
a $_{\text {Values are means } \pm \text { SD of triplicate experiments; }}{ }^{\mathrm{b}}$ Positive control substance.
\end{tabular}

\section{Discussion}

Seven alkaloids, containing the characteristics of a pyrrole ring and an aldehyde group, were isolated from the edible mushroom Phlebopus portentosus. Until now, nearly 200 naturally occurring alkaloids with a pyrrole-2-aldehyde moiety have been reported. These kind of alkaloids are widely distributed in plants, microorganisms, and marine invertebrates [16-19]. However, compounds 1-7 with the pyrrole-2-aldehyde group were first isolated from the edible mushroom Phlebopus portentosus. Meanwhile, three new pyrrole alkaloids have also enriched the chemical diversity of this kind of alkaloids. In addition, we investigated all the compounds for their neuroprotective properties and acetylcholine esterase (AChE) inhibition activities. In cell survival over the $\mathrm{H}_{2} \mathrm{O}_{2}$ group at $10 \mu \mathrm{M}$, compound 7 significantly attenuated SH-SY5Y cell damage induced by $\mathrm{H}_{2} \mathrm{O}_{2}$, noting a $26.5 \%$ increase, while other compounds displayed moderate or mild activities ranging from a 5.84\% to $15.7 \%$ increase. Compounds 5 and 7 better attenuated SH-SY5Y cell damage induced by $\mathrm{H}_{2} \mathrm{O}_{2}$ than other compounds, which suggested that pyrrole alkaloids with another aromatic ring in their indole ring may affect the pharmacological activity regarding SH-SY5Y cell damage induced by $\mathrm{H}_{2} \mathrm{O}_{2}$.

\section{Materials and Methods}

\subsection{General Experimental Procedures}

Optical rotation data were measured with a Perkin-Elmer 341 digital polarimeter (PerkinElmer, Norwalk, CT, USA). UV and IR data spectra were recorded on Shimadzu UV2550 and FTIR-8400S spectrometers (Shimadzu, Kyoto, Japan). CD spectra were obtained using a JASCO J-815 spectropolarimeter. NMR spectra were obtained using a Bruker AV III 600 NMR spectrometer with chemical shift values presented as $\delta$ values having TMS as the internal standard. HRESIMS was performed using an LTQ-Orbitrap XL spectrometer (Thermo Fisher Scientific, Boston, MA, USA). Column chromatography (CC) was performed using a silica gel (100-200 and 300-400 mesh, Qingdao Marine Chemical Plant, Qingdao, China). Precoated silica gel $\mathrm{GF}_{254}$ plates (Zhi Fu Huang Wu Pilot Plant of Silica Gel Development, Yantai, China) were used for TLC. All solvents used were of analytical grade (Beijing Chemical Plant, Beijing, China).

\subsection{Fungal Material}

The mushrooms of $P$. portentosus were collected from Haikou City, Hainan Province, China, in April 2017. The botanical identification of the mushroom was done by Professor Xi-long Zheng, Hainan 
Branch Institute of Medicinal Plant Development, Chinese Academy of Medical Sciences \& Peking Union Medical College, where a voucher specimen (No. M20170425) was deposited.

\subsection{Isolation and Purification of Compounds $\mathbf{1}-\mathbf{7}$}

The dried fruiting bodies of P. portentosus $(0.5 \mathrm{~kg}$ ) were extracted with EtOAc twice. The solvents were filtrated and evaporated in vacuo to give the total extract $(43 \mathrm{~g})$, and this residue was subjected to column chromatography (CC) over silica gel (100-200 mesh) eluted with a gradient of $\mathrm{CH}_{2} \mathrm{Cl}_{2}-\mathrm{MeOH}$ $(0: 1 \rightarrow 1: 0)$ to obtain six fractions $(\mathrm{A}-\mathrm{F})$. Fraction $\mathrm{C}(8.2 \mathrm{~g})$ was subjected to chromatography repeatedly over silica gel CC eluting with $\mathrm{CH}_{2} \mathrm{Cl}_{2}-\mathrm{MeOH}(80: 0,60: 1,40: 1,20: 1,10: 1, v / v)$, and was finally purified by semipreparative HPLC (MeOH-H $\left.{ }_{2} \mathrm{O} / 80: 20\right)$ to give compounds $\mathbf{1}(3.4 \mathrm{mg}), \mathbf{2}(2.7 \mathrm{mg})$, and $\mathbf{6}(8.0 \mathrm{mg})$. Fraction D (1.3 g) was subjected to chromatography using ODS MPLC elution with $\mathrm{MeOH}-\mathrm{H}_{2} \mathrm{O}$ (30:70; 90:10; 100:0, $v / v$ ), to yield three fractions (Fr. D1-3), and Fr. D2 was separated through semipreparative HPLC using a mobile phase of $\mathrm{MeOH}-\mathrm{H}_{2} \mathrm{O}(85: 15, v / v)$ to afford compounds $3(2.1 \mathrm{mg})$ and $4(1.8 \mathrm{mg})$. Similarly, fraction E (2.9 g) was isolated through ODS MPLC elution with $\mathrm{MeOH}-\mathrm{H}_{2} \mathrm{O}$ (30:70; 90:10; 100:0, $v / v)$, and prepared by semipreparative HPLC to give compounds $5(12.4 \mathrm{mg})$ and $7(9.1 \mathrm{mg})$.

\subsection{Characterization of Compounds 1-3}

phlebopine A (1), White powder (MeOH); UV (MeOH) $\lambda_{\max }(\log \varepsilon) 291$ (3.52) nm; IR (film) $v_{\max }$ 3430, 2928, 2854, 2735, $1647 \mathrm{~cm}^{-1} ;{ }^{1} \mathrm{H}$ - and ${ }^{13} \mathrm{C}-\mathrm{NMR}$ data (DMSO- $d_{6}$ ), see (Table 1); HRESIMS $\mathrm{m} / z$ $204.0997[\mathrm{M}+\mathrm{Na}]^{+}$. (Calculated for. 204.1000, $\mathrm{C}_{10} \mathrm{H}_{15} \mathrm{NO}_{2} \mathrm{Na}$ ).

phlebopine B (2), White powder (MeOH); UV (MeOH) $\lambda_{\max }(\log \varepsilon) 294$ (3.76) nm; IR (film) $v_{\max }$ $3428,2935,2841,2732,1650 \mathrm{~cm}^{-1} ;{ }^{1} \mathrm{H}$ - and ${ }^{13} \mathrm{C}-\mathrm{NMR}$ data (DMSO- $d_{6}$ ), see (Table 1); HRESIMS $\mathrm{m} / \mathrm{z}$ 218.1132 [M + Na] $]^{+}$. (Calculated for. 218.1157, $\mathrm{C}_{11} \mathrm{H}_{17} \mathrm{NO}_{2} \mathrm{Na}$ ).

phlebopine C (3), White powder (MeOH); UV (MeOH) $\lambda_{\max }(\log \varepsilon) 292(3.93) \mathrm{nm}$; IR (film) $v_{\max }$ 3368, 2954, 2830, 2728, $1672 \mathrm{~cm}^{-1} ; \mathrm{CD}(\mathrm{MeOH}): 330(\Delta \varepsilon-8.7) ;{ }^{1} \mathrm{H}-$ and ${ }^{13} \mathrm{C}-\mathrm{NMR}$ data $\left(\mathrm{CDCl}_{3}\right)$, see (Table 1); HRESIMS $m / z 262.1034$ [M + Na] ${ }^{+}$. (Calculated for. 262.1055, $\mathrm{C}_{12} \mathrm{H}_{17} \mathrm{NO}_{4} \mathrm{Na}$ ).

\subsection{Neuroprotective Activity Assay}

The neuroprotective activity was tested against $\mathrm{H}_{2} \mathrm{O}_{2}$-induced injury in SH-SY5Y neuroblastoma cells according to the reported protocol $[20,21]$. Cells were maintained at $37^{\circ} \mathrm{C}$ in a humidified atmosphere containing $5 \% \mathrm{CO}_{2}$. In 96-well plates, cells were seeded at a density of $2 \times 10^{5}$ cells $/ \mathrm{mL}$ in MEM/F12 medium supplemented with $10 \%(v / v)$ fetal bovine serum. Then, cells were incubated with the serum-free MEM/F12 medium substituting the original medium after $24 \mathrm{~h}$. Test compounds and the positive control $\mathrm{N}$-acetyl-L-cysteine were dissolved in DMSO to prepare $10^{-2} \mathrm{M}$ stock solutions and then diluted to the corresponding concentrations with the cell culture medium. Cells were incubated with test compounds for $2 \mathrm{~h}$ prior to treatment with $10 \mu \mathrm{M} . \mathrm{H}_{2} \mathrm{O}_{2}$ for another $24 \mathrm{~h}$ without changing the culture medium. $10 \mu \mathrm{L}$ of MTT ( $2 \mathrm{mg} / \mathrm{mL}$, Sigma, Tokyo, Japan, purity: $98 \%$ ) was then added to each well and incubated at $37^{\circ} \mathrm{C}$ for $3 \mathrm{~h}$. The cells were finally lysed with $100 \mu \mathrm{L}$ of DMSO, and the amount of MTT formazan was measured at $490 \mathrm{~nm}$ using a microplate reader (M200, TECAN, Austria $\mathrm{GmbH}$, Vienna, Austria).

\subsection{Acetylcholinesterase Inhibitory Assay}

Inhibition of acetylcholinesterase activity was measured by Atanasova's spectrophotometric method with slight modifications [22,23]. The hydrolysate of acetylthiocholine, which reacts with 5,5'-dithiobis-(2-nitrobenzoic acid) (DTNB), can be detected at $405 \mathrm{~nm}$. On the 96-well plate was placed: $50 \mu \mathrm{L}$ of AChE in buffer phosphate (PH 7.6) and $50 \mu \mathrm{L}$ of the sample dissolved in the same buffer were added to the wells. The plates were incubated for $30 \mathrm{~min}$ at room temperature before the addition of the substrate solution (0.5 M DTNB, $0.6 \mathrm{mM}$ ATCI in buffer, $\mathrm{pH}$ 7.6). The absorbances were read at $405 \mathrm{~nm}$ using a microplate reader. 
Supplementary Materials: Supplementary data associated with this article can be found, in the online version.

Author Contributions: G.M. and X.X. conceived and designed the experiments; Zhaocui S. and M.H. performed the experiments; Zhonghao S., N.Z., and J.Y. helped during structural elucidation.

Acknowledgments: The work was financially supported by the Technological Large Platform for Comprehensive Research and Development of New Drugs in the Twelfth Five-Year "Significant New Drugs Created" Science and Technology Major Projects (No. 2012ZX09301-002-001-026), the National Natural Sciences Foundation of China (No. 81502945), and the CAMS Innovation Fund for Medical Sciences (CIFMS) (No. 2017-I2M-1-013).

Conflicts of Interest: The authors declare no conflicts of interest.

\section{References}

1. Longvah, T.; Deosthale, Y.G. Compositional and nutritional studies on edible wild mushroom from northeast India. Food Chem. 1998, 63, 331-334. [CrossRef]

2. Manzi, P.; Aguzzi, A.; Pizzoferrato, L. Nutritional value of mushrooms widely consumed in Italy. Food Chem. 2001, 73, 321-325. [CrossRef]

3. Wani, B.A.; Bodha, R.H.; Wani, A.H. Nutritional and medicinal importance of mushrooms. J. Med. Plant Res. 2010, 4, 2598-2604.

4. Kawagishi, H.; Shimada, A.; Shirai, R.; Okamoto, K.; Ojima, F.; Sakamoto, H.; Ishiguro, Y.; Furukawa, S. Erinacines, A, B and C, strong stimulators of nerve growth factor (NGF)-synthesis, from the mycelia of Hericium erinaceum. Tetrahedron Lett. 1994, 35, 1569-1572. [CrossRef]

5. Yin, X.; Feng, T.; Li, Z.H.; Dong, Z.J.; Li, Y.; Liu, J.K. Highly oxygenated meroterpenoids from fruiting bodies of the mushroom Tricholoma terreum. J. Nat. Prod. 2013, 76, 1365-1368. [CrossRef] [PubMed]

6. Zhao, Z.Z.; Chen, H.P.; Wu, B.; Zhang, L.; Li, Z.H.; Feng, T.; Liu, J.K. Matsutakone and Matsutoic Acid, two (nor)steroids with unusual skeletons from the edible mushroom Tricholoma matsutake. J. Organ. Chem. 2017, 82, 7974-7979. [CrossRef] [PubMed]

7. Ji, K.P.; Cao, Y.; Zhang, C.X.; He, M.X.; Liu, J.; Wang, W.B.; Wang, Y. Cultivation of Phlebopus portentosus in southern China. Mycol. Prog. 2011, 10, 293-300. [CrossRef]

8. Ji, K.; Zhang, C.; Zeng, Y.; Liu, C.; He, M.; Wang, W. Artificial fungal colony and its fruiting of Phlebopus portentosus (Boletaceae) in pot. Acta Botanica Yunnanica 2007, 29, 554-558.

9. Yang, Z.; Zang, M. Tropical Affinities of Higher Fungi in Southern China. Acta Botanica Yunnanica 2003, 25, 129-144.

10. Joung Youn, U.; Kil, Y.S.; Nam, J.W.; Jin Lee, Y.; Kim, J.; Lee, D.; Lee, J.H.; Seo, E.K. New Pyrrole Alkaloids with Bulky N-Alkyl Side Chains Containing Stereogenic Centers from Lycium chinense. Helv. Chim. Acta 2013, 96, 1482-1487. [CrossRef]

11. Zhan, Z.J.; Shan, W.G.; Bai, H.B.; Zhang, L.Y. A new alkaloid from the mycelium of Inonotus obliquus. J. Chem. Res. 2014, 38, 245-246. [CrossRef]

12. Yang, J.J.; Yu, D.Q. Synthesis of ganoderma alkaloid A and B. Yao Xue Xue Bao 1990, 25, 555-559. [PubMed]

13. Shan, W.-G.; Wang, Y.; Ma, L.-F.; Zhan, Z.-J. A new pyrrole alkaloid from the mycelium of Inonotus obliquus. J. Chem. Res. 2017, 41, 393. [CrossRef]

14. Li, M.; Xiong, J.; Huang, Y.; Wang, L.-J.; Tang, Y.; Yang, G.-X.; Liu, X.-H.; Wei, B.-G.; Fan, H.; Zhao, Y. Xylapyrrosides A and B, two rare sugar-morpholine spiroketal pyrrole-derived alkaloids from Xylaria nigripes: Isolation, complete structure elucidation, and total syntheses. Tetrahedron 2015, 71, 5285-5295. [CrossRef]

15. Shigematsu, H.; Kurata, T.; Kato, H.; Fujimaki, M. Formation of 2-(5-Hyclroxymethyl-2-formylpyrrol-1-yl) alkyl Acid Lactones on Roasting Alkyl- $\alpha$-amino Acid with d-Glucose. Agric. Biol. Chem. 1971, 35, 2097-2105. [CrossRef]

16. Xiong, J.; Huang, Y.; Wu, X.Y.; Liu, X.H.; Fan, H.; Wang, W.; Zhao, Y.; Yang, G.X.; Zhang, H.Y.; Hu, J.F. Chemical constituents from the fermented mycelia of the medicinal fungus Xylaria nigripes. Helv. Chim. Acta 2016, 99, 83-89. [CrossRef]

17. Xiong, L.; Peng, C.; Xie, X.F.; Guo, L.; He, C.J.; Geng, Z.; Wan, F.; Dai, O.; Zhou, Q.M. Alkaloids isolated from the lateral root of Aconitum carmichaelii. Molecules 2012, 17, 9939-9946. [CrossRef] [PubMed] 
18. Compagnone, R.S.; Oliveri, M.C.; Piãna, I.C.; Marques, S.; Rangel, H.R.; Dagger, F.; Suárez, A.I.; Gómez, M. 5-alkylpyrrole-2-carboxaldehydes from the caribbean sponges mycale microsigmatosa and desmapsamma anchorata. Nat. Prod. Lett. 1999, 13, 203-211. [CrossRef]

19. Mao, S.C.; Liu, Y.; Morgan, J.B.; Jekabsons, M.B.; Zhou, Y.D.; Nagle, D.G. Lipophilic 2,5-disubstituted pyrroles from the marine sponge mycale sp. inhibit mitochondrial respiration and hif-1 activation. J. Nat. Prod. 2009, 72, 1927-1936. [CrossRef] [PubMed]

20. Tang, Y.; Fu, Y.; Xiong, J.; Li, M.; Ma, G.-L.; Yang, G.-X.; Wei, B.-G.; Zhao, Y.; Zhang, H.-Y.; Hu, J.-F.; et al. lycodine-type alkaloids from Lycopodiastrum casuarinoides. J. Nat. Prod. 2013, 76, 1475-1484. [CrossRef] [PubMed]

21. Taveira, M.; Sousa, C.; Valentão, P.; Ferreres, F.; Teixeira, J.P.; Andrade, P.B. Neuroprotective effect of steroidal alkaloids on glutamate-induced toxicity by preserving mitochondrial membrane potential and reducing oxidative stress. J. Steroid Biochem. Mol. Biol. 2014, 140, 106-115. [CrossRef] [PubMed]

22. Atanasova, M.; Stavrakov, G.; Philipova, I.; Zheleva, D.; Yordanov, N.; Doytchinova, I. Galantamine derivatives with indole moiety: Docking, design, synthesis and acetylcholinesterase inhibitory activity. Bioorganic Med. Chem. 2015, 23, 5382-5389. [CrossRef] [PubMed]

23. Mukherjee, P.K.; Kumar, V.; Mal, M.; Houghton, P.J. Acetylcholinesterase inhibitors from plants. Phytomedicine 2007, 14, 289-300. [CrossRef] [PubMed]

Sample Availability: Samples of the compounds 1-7 are available from the authors. 